\title{
Plastic hinge assessment of RC moment-resisting frames
}

\author{
Mahmoud AlHassan ${ }^{1 *}$, Mohamad Abdelrahim ${ }^{1}$ \\ ${ }^{I}$ Civil Engineering Department, Near East University, Nicosia, via Mersin 10, Turkey
}

ARTICLE INFO

ARTICLE HISTORY:

Received: 21 January 2020

Revised: 06 May 2020

Accepted: 06 May 2020

Published: 27 June 2020

\section{KEYWORDS:}

Moment-resisting frame, plastic hinge, pushover analysis, pushover curve

\begin{abstract}
A B S T R A C T
This paper gives a short introduction about various kinds of analysis, plastic hinges, momentresisting frames (MRFs) in RC Structures. It likewise gives computer software ETABS displaying and an investigation of structures concerning Pushover Analysis. The fundamental reason for this examination is to apply a push to all models, analyse and get a reasonable thought regarding their behaviour. The behaviour of these structures likewise was evaluated considering various variables such as the changes in the number of floors, spans length, reinforcements' yield strength and characteristic strength of concrete. This investigation incorporates the moment-resisting frames (MRFs) having 4, 7, and 10 storeys and a relative report for all models' outcomes. Pushover analysis is a nonlinear static analysis used to determine the relationship between strength and displacement in order to evaluate the performance of the RC frame structure. It was found that the plastic hinge may be assessed using parameters such as span lengths and the number of storeys. When the number of storeys increases, the elastic stiffness value decreases and when the span length increases the elastic stiffness also decreases. The collapse of members happens only when there is a formation of 3 hinge mechanisms. Plastic hinge colours have been given, and each colour has its significance to permit a good design.
\end{abstract}

\section{INTRODUCTION}

Static and dynamic are two types of seismic analyses that are being used in most cases. Equivalent lateral force and pushover belong to the linear and non-linear static analysis, respectively. Response spectrum and time-history belong to the linear and non-linear dynamic analysis, respectively. To analyse a structure considering the linear static technique is great. However, the ultimate load that it could bear precisely may not be evaluated properly by the designer due to the assumption made in fixing the maximum load that the structure can support as a result of load that first cause stress somewhere in the structure. This situation renders the linear static method not economical, and an alternative to this method is needed. The method that can provide the maximum load that the structure can bear is known as pushover analysis (Hassaballa, 2014). Pushover analysis is a non-linear static method where the structure is subjected to a push (considered as a lateral load) at its top floor until it collapses. The maximum load and displacement are those points corresponding to the collapse of the structure at the pushover curve from ETABS (Kamath et al. 2016; Vassilis et al. 2008; Girgin \& Darılmaz, 2007). Relative to certain elements, frame elements have a costeffective and precise approach for structure nonlinear response analysis. A conventional and traditional approach, the displacement-based method, was used to derive frame elements using computational methods based on estimated displaced component shapes (Li et al., 2012).

Moment-resisting frames (MRFs) are frames made up using beams and columns connected together. MRFs are capable of resisting lateral forces due to the rigid connection at the joints between beams and columns (Bruneau et al. 2011; Izadinia et al., 2012; Vona and Mastrobetti, 2018). The pushover analysis is applied to MRFs in order to check the behaviour of the structure. The behaviour of the structure is assessed with respect to the elastic stiffness, which is the ability of a structure to resist deformation under the load's application. The objective is to ensure that the structure remains stiff after its construction process, as said by Das and Choudary, 2019. The ratio of the base shear to the displacement is known as stiffness. In case the load applied is more than the maximum load required to be applied on members, deformation takes place and the plastic hinge forms. The moment which caused the formation of this plastic hinge is the plastic moment. For the collapse mechanism to occur, there must be a 3 hinges' formation in a member or an additional plastic hinge must be added when 
considering each degree of static indeterminacy of the beam. $\mathrm{N}=$ Static indeterminacy degree +1 , where $\mathrm{N}$ is the number of plastic hinges (Scott \& Fenves, 2006; Pokhrel \& Bandelt, 2019).

\section{METHODOLOGY}

This section copes with the methodology utilized in this study. The static method is the main analysis method utilized in this study. The first method to be performed is the linear static method. Modelling, analysis and design were performed using this method in order to get the member sizes. After performing the first method, the nonlinear static method is performed using ETABS until when the structure collapses (Shah \& Patel, 2011; Qamaruddin, 2016; Abhilash et al., 2009). Materials properties, modelled frames, loads applied and pushover analysis are the significant topics of this section.

\subsection{Materials properties}

Materials utilized in this paper are steel and concrete. Steel utilized served as rebar to the structure. The applied properties of materials are given in Table 1.

Table 1. Materials properties applied

\begin{tabular}{|c|c|c|}
\hline Materials properties & $\begin{array}{c}\text { Concrete } \\
\left(\mathbf{N} / \mathbf{m m}^{2}\right)\end{array}$ & $\begin{array}{c}\text { Steel } \\
\left(\mathbf{N} / \mathbf{m m}^{2}\right)\end{array}$ \\
\hline$f_{y}$ & - & 420 \\
\hline$f_{c}^{\prime}$ & $360(\mathrm{C} 36)$ & - \\
\hline $\mathrm{E}$ & 24855 & 199947 \\
\hline
\end{tabular}

\subsection{Modelled frames}

Nine models have been modelled in this paper, and all are 2D RC frames. The number of storeys (S) and span lengths (L) are the two parameters considered for analysis.

\subsubsection{The labelling system applied for frames}

The following labelling system has been applied for frames: ST-N-S-L-H- $f_{c}^{\prime}-f_{y}$. Coding has been applied,

where:

ST: The structure type (RC: Reinforced concrete),

$\mathrm{N}$ : Number of spans (5),

S: Number of storeys (4, 7 and 10),

$\mathrm{H}$ : Storey height $(3.5 \mathrm{~m})$,

L: Span length $(5.5 \mathrm{~m}, 6 \mathrm{~m}$ and $6.5 \mathrm{~m})$,

$f_{c}^{\prime}$ : Compressive strength of concrete,

$f_{y}$ : Rebar Yield strength.

\subsubsection{Frame's geometry}

Frames geometries that have been used for all 9 models are given in Table 2.

Table 2. Dimensions for beams and columns

\begin{tabular}{|c|c|}
\hline Member type & Member size $\mathbf{( m m )}$ \\
\hline Beams & $300 \times 600$ \\
\hline Columns & $300 \times 600$ \\
\hline
\end{tabular}

\subsection{Gravity load utilized}

Three loads such as super dead, live and dead have been considered in this study. The dead load is calculated automatically by the software, and the live, as well as dead loads, are $7 \mathrm{kN} / \mathrm{m}$ and $10 \mathrm{kN} / \mathrm{m}$ respectively.

\subsection{Pushover analysis (PA)}

\subsubsection{Pushover analysis applied}

Pushover analysis is a nonlinear method utilized to anticipate the seismic hazard or any lateral load such as wind (Patil et al., 2017). Capacity spectrum and displacement coefficient methods are the two types of pushover analysis. The displacement coefficient method is the one utilized in this study, and the distance for hinges' location is $10 \%$ of the whole members' distance at both ends (Kashid et al., 2015). As the name indicates "Pushover", means to push the structure until it arrives at its most extreme ability to twist. It helps to understand the poor formality and splitting of a structure and gives a sort of reasonable comprehension of the twisting of building and development of plastic hinges in the structure (Doshi, 2015).

\subsubsection{Stiffness and pushover curve}

The curve found after the analysis of the frame using pushover in ETABS is called pushover curve. The following are three ways to specify the load 'P' to be applied to the top storey of the frame (Chandrasekaran \& Roy, 2006):

- To specify the full load directly;

- To specify the displacement and from it, the load is automatically applied by the software;

- The quasi-static method

Among all the above three ways of specifying the push magnitude, the second way is used in this paper, that is the displacement's specification. It helps to do a simulation of what may happen in a real situation (Boroujeni et al., 2013). The elastic stiffness $(\mathrm{K})$ is calculated from results found on this pushover curve, taking the ratio of base shear to the displacement (Youcef et al., 2018). These values are selected considering the first plastic hinge formation on the curve. Fig. 1 shows the example of selected values from the pushover curve for stiffness calculation. 


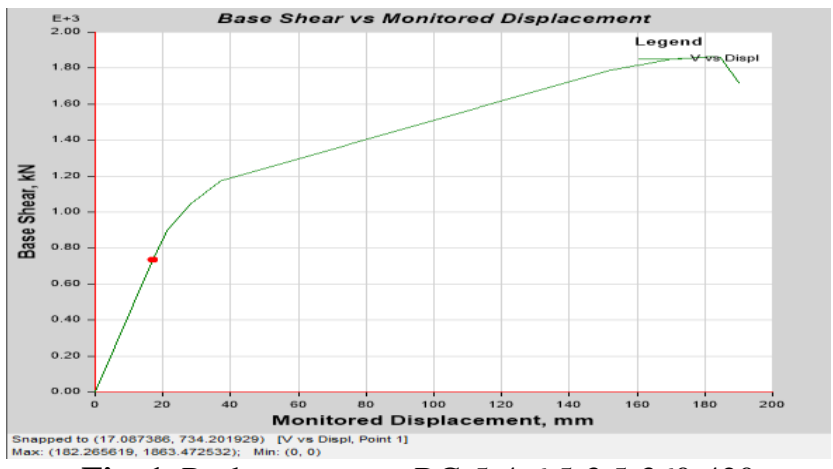

Fig. 1. Pushover curve, RC-5-4-6.5-3.5-360-420

$$
K=\frac{V s}{D s}
$$

where:

$K$ : Elastic stiffness factor in $\mathrm{kN} / \mathrm{mm}$,

$D s$ : Displacement at the first plastic hinge formation,

$V s$ : Base shear at the first plastic hinge formation

(Ngenge \& Wafi, 2020; Sarhan \& Raslan, 2020).

\section{RESULTS AND DISCUSSIONS}

This section consists of results and discussions of 2D RC frames that were analysed based on the study, as explained in previous sections. These results focus mainly on the assessment of plastic hinges in terms of elastic stiffness. The factors considered in this study are the span lengths and the number of floors. Results and discussions section include two main parts which are the results according to the formation of plastic hinges and results with respect to the pushover curve's values. They are as explained below with graphs.

\subsection{Results according to the formation of plastic hinges}

Fig. 2 illustrates an example of hinges' formation in a RC-5-10-6-3.5-360-420. It was taken from ETABS. Hinges are represented by dots having different colours on beams and columns. Their meanings are as follow: Green dots represent the starting of yielding (BC), blue colours represent the ultimate strength $(\mathrm{CD})$, pink colours represent the residual strength (DE) and the red colours represent the maximum residual strength formation (after E) (Yadav et al., 2017). In Fig. 2, the second storey has to be well designed since it shows that the plastic hinges at that storey are more critical than in other storeys. Additionally, storey one too needs to be well reinforced since it is also a critical storey after storey two. If plastic hinges colours are green in all the structure, it means that the structure is safer. In case they are red in all structure, it means that the structure is not safe and need to be revised. The above explanation is with respect to the given example of plastic hinges' formation, as shown in Fig. 2.

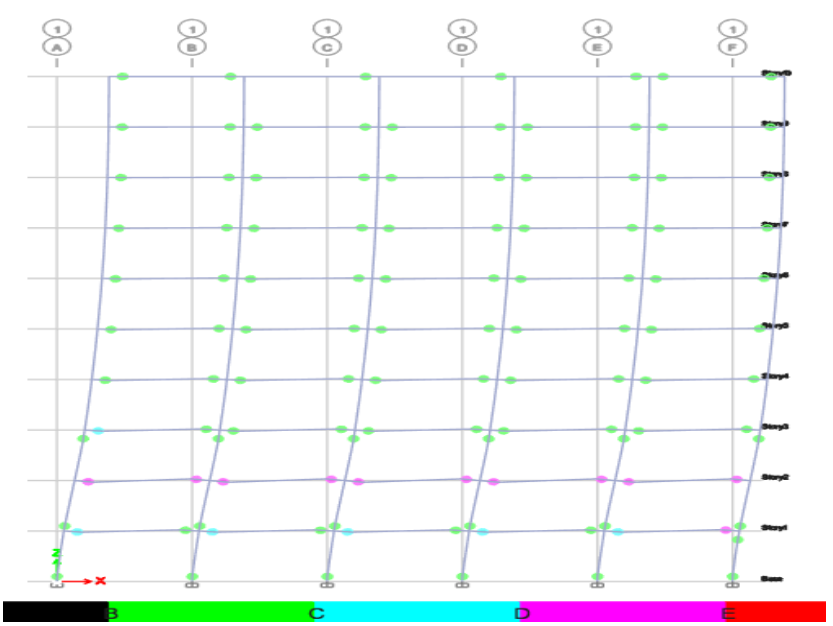

Fig. 2. Plastic hinge formation, RC-5-10-6-3.5-360-420

\subsection{Results with respect to the pushover curve's values}

When it comes to pushover curve, two parameters come into consideration. They are the base shear and the displacement. The base shear is the base reaction with respect to the displacement of the structure as the lateral load acts. The ratio of the base shear to the displacement gives the elastic stiffness. That is why the assessment of the plastic hinge is done with respect to the stiffness. Results in this section are related to the effect of the number of storeys and span lengths on the stiffness of moment-resisting frames (MRFs).

\subsubsection{The effect of the number of storeys on the stiffness of MRFs}

The stiffness of a structure is the important factor that needs to be known. It is affected by certain parameters such as the number of storeys or the type of structure such as low, mid- and high-rise buildings. It has been found that the elastic stiffness is high in low-rise buildings when compared to mid- and high-rise buildings. Similarly, mid-rise buildings have more stiffness than high-rise buildings.

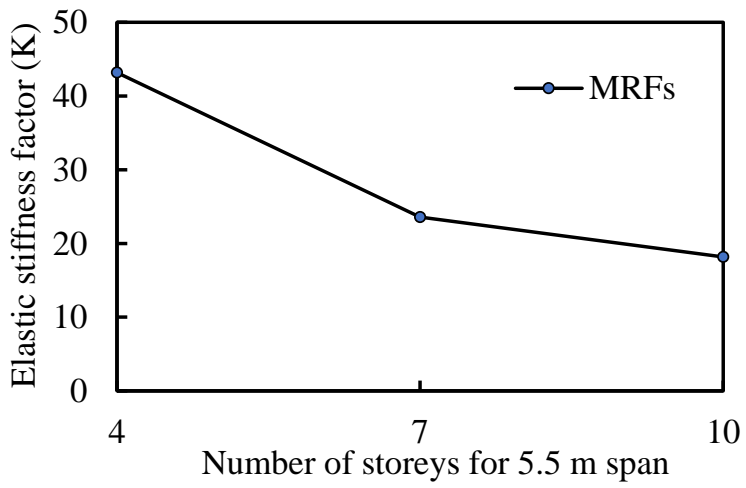

Fig. 3. $K$ versus different number of storeys $(S), M R F$ 
This implies that when the height of a structure goes on increasing, the elastic stiffness of that structure goes on decreasing. The Fig. 3 and Table 3 show an example justifying what has been discussed above. Its coding is as follow: RC-5-(4, 7, 10)-5.5-3.5-360-420.

Table 3. K versus the different number of storeys (S)

\begin{tabular}{|c|c|}
\hline $\mathbf{S}$ & $\mathbf{K}$ \\
\hline $\mathbf{4}$ & 43.17 \\
\hline $\mathbf{7}$ & 23.57 \\
\hline $\mathbf{1 0}$ & 18.17 \\
\hline
\end{tabular}

\subsubsection{The effect of span lengths on the stiffness of MRFs}

The span length is also a parameter that affects the elastic stiffness significantly. It founds that when the span length increases the elastic stiffness decreases. The reason is that when the span length is less, the columns are closer to each other, hence the stiffness will be more. Fig. 4 and Table 4 show the effect of span lengths on the stiffness of moment-resisting frames (MRFs).

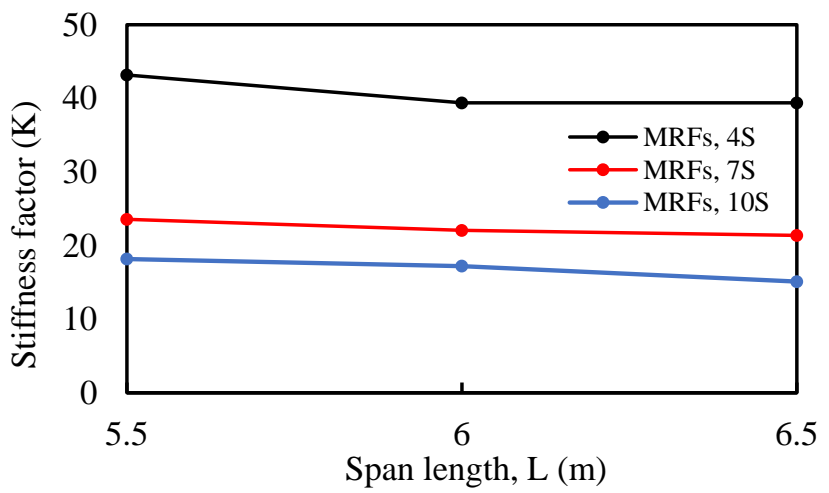

Fig. 4. K versus different span lengths, MRF

Table 4. K versus different span lengths (L), MRF

\begin{tabular}{|c|c|c|c|}
\hline \multirow{2}{*}{$\mathbf{S}$} & \multicolumn{3}{|c|}{$\mathbf{K}$} \\
\cline { 2 - 4 } & $\mathbf{5 . 5} \mathbf{~ m}$ & $\mathbf{6} \mathbf{~ m}$ & $\mathbf{6 . 5} \mathbf{~ m}$ \\
\hline $\mathbf{4}$ & 43.17 & 39.39 & 20.09 \\
\hline $\mathbf{7}$ & 23.57 & 22.06 & 21.38 \\
\hline $\mathbf{1 0}$ & 18.17 & 17.21 & 15.11 \\
\hline
\end{tabular}

\section{CONCLUSIONS}

The plastic hinge assessment of RC moment-resisting frames has been done as specified in the previous sections. Different definitions have been done in order to permit a clear understanding of the paper. The methodology helped to understand the methods used in the paper and the results' part helped to understand the outcomes. It was found that the plastic hinge may be assessed using parameters such as span lengths and the number of storeys. When the number of storeys increases, the elastic stiffness value decreases and when the span length increases, the elastic stiffness decreases. The collapse of members happens only when there is a formation of 3 hinge mechanisms. Different plastic hinge colours have been given, and each colour has its meaning. The reinforcements of members during the design shall be done, taking into consideration the colours' of hinge formed. For further studies where the lateral load is taken into consideration, authors suggest the application of lateral load resisting systems such as shear walls or bracings to the structure. Finally, all stiffness values were calculated, taking the ratio of base shear to the displacement, considering the first hinge formation on the pushover curve of each model.

\section{REFERENCES}

[1] Abhilash, R. et al. (2009). Effect of lateral load patterns in pushover analysis. $10^{\text {th }}$ National conference on technological trends (NCTT09). At Ttrivandrum, India, Volume: College of Engineering Trivandrum, 1-5.

[2] Boroujeni, A. K. et al. (2013). Evaluation of various methods in FEMA356 compares to FEMA440. Journal of Civil Engineering and Construction Technology, 4(2), 51-55.

[3] Bruneau, M. et al. (2011). Ductile Design of Steel Structures. ( $2^{\text {nd }}$ ed.). McGraw-Hill Companies, pp. 345-348.

[4] Chandrasekaran, S., \& Roy, A. (2006). Seismic evaluation of multi-story RC frame using modal pushover analysis. Springer, nonlinear dynamics, 4.

[5] Das, S., \& Choudhury, S. (2019). Influence of effective stiffness on the performamce of the RC frame buildings designed using displacement-based method and evaluation of column effective stiffness using ANN. Elsevier, Engineering Structures, 197, 109353. https://doi.org/10.1016/j.engstruct.2019.109354.

[6] Doshi, J. (2015). What is a pushover analysis. Quora. https://www.quora.com/What-is-a-pushover-analysisHow-is-it-performed-in-STAAD-Pro-What-is-thedifference-between-pushover-and-seismic-analysis-inSTAAD-Pro-A-Detailed-answer-would-be-welcome

[7] Girgin, K., \& Darılmaz, K. (2007). Seismic response of infilled framed buildings using pushover analysis, ARI The Bulletin of the Istanbul Technical University, $54(5)$.

[8] Hassaballa, A. E. et al. (2014). Pushover Analysis of Existing 4 storey RC Flat Slab Buiding. International Journal of Sciences: Basics and applied Research (IJSBAR), 16, 246-247.

[9] Izadinia, M. et al. (2012), response modification factor for steel moment-resisting frames by different pushover analysis methods. ELSEVIER, Journal of constructional steel research, 2-4. 
[10] Kamath, K. et al. (2016). An analytical study on performance of a diagrid structure using nonlinear static pushover analysis. Science direct, 8, 90-92.

[11] Kashid, N. M. et al. (2015). Performance-based seismic analysis for buildings in India, Pune, Maharashtra, India. International Jornal of the modern trend in engineering and science, 4(3), 47-50.

[12] Li, S. et al. (2012). Evaluation of displacement-based, force-based, and plastic hinge elements for structural non-linear static analysis. SAGE Jornal, 15(3), 477488.

[13] Ngenge, J. P. L., \& Wafi, A. M. S. (2020). Assessment of plastic hinge in RC structures with and without shear walls applying pushover analysis. International Journal of Advanced Engineering, Sciences and Applications, 1(1), 11-18. Retrieved from https://www.londontechpress.co.uk/index.php/ijaesa/a rticle/view/27

[14] Patil, S. et al. (2017). Pushover Analysis of MultiStorey Building. International Jornal of the modern trend in engineering and science, 4(3), 47-50.

[15] Pokhrel, M., \& Bandelt, M. J. (2019). Plastic hinge behaviour and rotation capacity in reinforced ductile concrete flexural members. Elsevier, engineering structures, 200, 2-4.

[16] Qamaruddin, S. (2016). Seismic response study of multi-storied reinforced concrete building with fluid viscous dampers. Research Gate, 33-36.

[17] Sarhan, O., \& Raslan, M. (2020). Study of the elastic stiffness factor of steel structures with different lateral load resisting systems. International Journal of Advanced Engineering, Sciences and Applications, 1(2), 6-11. Retrieved from https://www.londontechpress.co.uk/index.php/ijaesa/a rticle/view/26

[18] Scott, M. H., \& Fenves, G. L. (2006). Plastic Hinge Integration Methods for Force-Based Beam-Column Elements. Journal of Structural Engineering, 244-252.

[19] Vassilis, K. et al. (2008). Evaluation of conventional and adaptive pushover analysis II: comparative results. Taylor \& Francis, Journal of earthquake engineering, 7-10.

[20] Vona, M. \& Mastroberti, M. (2018). Estimation of the behavior factor of existing RC-MRF buildings. Springer Link, 17(1), 191-204.

[21] Yadav, R. et al. (2017). Performance Levels of RC Structures with Non-Linear Pushover Analysis. Journal of engineering research and application, 7(4), 1-8.

[22] Youcef, M. et al. (2018). Seismic performance of RC building using spectrum response and pushover analyses. Springer international publishing, 4. 